\title{
Changes in Soil Phosphorus Pools and Chemical Properties under Liming in Nitisols of Farawocha, South Ethiopia
}

\author{
Fikeremareyam Chulo $\mathbb{D}^{1},{ }^{1}$ Fanuel Laekemariam ${ }^{\circ},{ }^{1}$ and Alemayehu Kiflu $\mathbb{D D}^{2}$ \\ ${ }^{1}$ Wolaita Sodo University, College of Agriculture, P.O. Box 138, Wolaita Sodo, Ethiopia \\ ${ }^{2}$ Hawassa University, College of Agriculture, Hawassa, Ethiopia \\ Correspondence should be addressed to Fanuel Laekemariam; laeke2005@yahoo.com
}

Received 13 February 2021; Revised 19 July 2021; Accepted 26 July 2021; Published 3 August 2021

Academic Editor: Teodoro M. Miano

Copyright ( $) 2021$ Fikeremareyam Chulo et al. This is an open access article distributed under the Creative Commons Attribution License, which permits unrestricted use, distribution, and reproduction in any medium, provided the original work is properly cited.

\begin{abstract}
Understanding the nutrient dynamics in acid soil is fundamental to carry out proper management. The study was conducted to investigate phosphorus $(\mathrm{P})$ pools and selected properties under different rates of lime for acid nitisols of Farawocha, Southern Ethiopia. Four lime rates incubated for a month in three replications were tested. The lime rates were $0 \mathrm{t} / \mathrm{ha}(0 \%), 5.25 \mathrm{t} / \mathrm{ha}(50 \%)$, $10.5 \mathrm{t} / \mathrm{ha}(100 \%)$, and $15.75 \mathrm{t} / \mathrm{ha}(150 \%)$. Lime requirement (LR) for $100 \%$ was calculated targeting soil $\mathrm{pH}$ of 6.5 . Data on the $\mathrm{P}$ pools such as soluble $\mathrm{P}(\mathrm{P}-\mathrm{sol})$ and bounded forms of $\mathrm{P}$ with iron $(\mathrm{Fe}-\mathrm{P})$, aluminum $(\mathrm{Al}-\mathrm{P})$, calcium $(\mathrm{Ca}-\mathrm{P})$, organic part (Org- $\mathrm{P})$, residual $\mathrm{P}$ (Res- $\mathrm{P})$, and total of $\mathrm{P}$ fractions were measured. In addition, changes in soil chemical properties such as $\mathrm{pH}$, exchangeable acidity, calcium $(\mathrm{Ca})$, magnesium $(\mathrm{Mg})$, sulfur $(\mathrm{S})$, iron $(\mathrm{Fe})$, copper $(\mathrm{Cu})$, boron $(\mathrm{B})$, zinc $(\mathrm{Zn})$, and manganese $(\mathrm{Mn})$ were analyzed. The result showed that total $\mathrm{P}$ was $357.5 \mathrm{mg} / \mathrm{kg}$. Compared to nontreated soil, liming at a rate of $15.75 \mathrm{t} / \mathrm{ha}$ significantly improved P-sol $\left(34.2 \%, r^{2}=0.88\right)$, Ca-P $\left(61.6 \%, r^{2}=0.92\right)$, and Res-P $\left(195 \%, r^{2}=0.94\right)$; however, it reduced Fe-P $\left(58.5 \%, r^{2}=-0.83\right)$, Al-P $\left(71 \%, r^{2}=-0.97\right)$, and Org-P $\left(19.1 \%, r^{2}=0.93\right)$. Overall, the P-associated fractions in the soil, regardless of the lime rates, were in the order of Org_P $>$ Res_P $>$ Fe_P $>$ Ca_P $>$ Al_P $>$ P-sol. Liming raised soil pH by 2.1 units (4.5 to 6.6) over nonlimed soil, whereas it reduced exchangeable acidity from 4.18 to $0.23 \mathrm{meq} / 100 \mathrm{~g}$ soil. Available $\mathrm{P}, \mathrm{Ca}, \mathrm{Mg}, \mathrm{S}, \mathrm{Cu}, \mathrm{Zn}$, and B contents were significantly improved with lime application. However, liming reduced Fe and $\mathrm{Mn}$ contents. In conclusion, these findings showed that liming facilitated the release of $\mathrm{P}$ from various pools, modified $\mathrm{pH}$ and exchangeable acidity, and resulted in beneficial changes for most of the soil chemical properties.
\end{abstract}

\section{Introduction}

Nitisols are deep, well-drained, red, tropical soils with diffuse horizon boundaries and a clay-rich "nitic" subsurface horizon that has typical "nutty," polyhedric, blocky structure elements with shiny ped faces, predominantly derived from basic parent rocks by strong weathering, but they are far more fertile than most other red tropical soils [1]. More than half of all the nitisols of tropical Africa are found in the Ethiopian highlands followed by Kenya, Congo, and Cameroon, among the most productive agricultural soils along with Vertisols, Luvisols, and Planosols [2]. Due to strong weathering and oxides of $\mathrm{Fe}$ and $\mathrm{Al}$ domination, nitisols usually have limited availability of phosphorus through fixation or retention $[3,4]$.
Phosphorus is the most yield-limiting plant nutrient in many regions of the world [5, 6], tropical Africa [7], and most Ethiopian soils $[8,9]$. The forms of $\mathrm{P}$ greatly influence its availability in the soil and subsequently influence productivity [10]. In many soils, $\mathrm{P}$ availability is heavily restricted by binding to $\mathrm{Fe}$ and $\mathrm{Al}[7,10,11]$. Even if the total soil $\mathrm{P}$ exceeds plant requirements, it is mostly in nonavailable forms for crop uptake [12] and locked in primary minerals, precipitated, adsorbed, or inorganically complexed forms, and only approximately 6\% (range of $1.5 \%-11 \%$ ) readily available to plants [13]. Inorganic P mostly consists of poorly soluble Ca phosphates and $\mathrm{Fe}$ and $\mathrm{Al}$ phosphates, respectively, in alkaline soils and acid soils [14]. Soil P chemistry is complex and $\mathrm{P}$ possibly transformed depending 
on the environment [15]; therefore accurate assessment of $\mathrm{P}$ availability in soils and precise prediction of $\mathrm{P}$ fertilizer requirements are increasingly important for sustainable agriculture [16]. Due to this, the investigation of $P$ fractions is important for the evaluation of its status and the chemical reactions in soil that influence soil fertility.

It was hypothesized that acidity and ensuing effects resulted in poor growth and that liming can correct these shortcomings. Due to this, the investigation of $\mathrm{P}$ fractions is important for the evaluation of its status and the chemical reactions in soil that influence soil fertility. Accordingly, this study evaluated the effects of lime on the dynamics of $\mathrm{P}$ fraction and the variation of some important soil chemical properties.

\section{Materials and Methods}

2.1. Description of the Study Area. The study was conducted on the Wolaita Sodo University research farm which has been established to develop site-specific technologies. The farm is located in Wolaita Zones of Southern Ethiopia. The farm, for many years, was owned and managed using traditional practices but the productivity was low; soil acidity and inadequate fertilizer application were among many factors causing low productivity. In the field, it was also noted that plant growth was extremely retarded. Prior soil test results of research farms soils had shown strongly acidic reaction with a $\mathrm{pH}$ value of 4.5. The study site called Farawocha, a 3.85 ha farmland, lies between $07^{\circ} 6^{\prime} 34.33^{\prime \prime}-07^{\circ} 9^{\prime} 0.23^{\prime \prime} \mathrm{N}$ and $037^{\circ} 34^{\prime} 54.29^{\prime \prime}-037^{\circ} 37^{\prime} 33.43^{\prime \prime} \mathrm{E}$ located $55 \mathrm{~km}$ west of Sodo, capital of Wolaita zone (Figure 1), and $325 \mathrm{~km}$ south of Addis Ababa, capital of Ethiopia, with an average altitude of $1592 \mathrm{~m}$ asl. The farm has a gentle slope (4-6\%) with monthly temperature ranging from 13 to $25^{\circ} \mathrm{C}$ and a bimodal rainy season with annual rainfall varying from 1184 to $1854 \mathrm{~mm}$ (Figure 2). According to [18], soils of the study area were grouped under "Sidralic Nitisols (Aric, Ochric)."

2.2. Sample Preparation and Soil Analysis. Soil samples were collected at a depth of $0-20 \mathrm{~cm}$ with 10 subsamples to make a composited soil sample and were processed (air-dried, ground, and passed through 2 and $0.5 \mathrm{~mm}$ sieves) and analyzed for selected chemical and physical properties following the standard procedure.

Particle size analysis for textural class determination was conducted by the Bouyoucos Hydrometer Method with Marshall's Triangular coordinate system $[19,20]$ and the bulk density was determined using the Core method (volumetric cylinder method) [21]. Soil $\mathrm{pH}$ was measured using a glass electrode $\mathrm{pH}$ meter with a ratio of $1: 2.5$ soil to water [20] and soil electrical conductivity (EC) was measured using an EC meter with the ratio of $1: 5$ soil to water [22]. The soil organic carbon (OC) content was determined by the wet oxidation method [23] and the total nitrogen (TN) content by the Kjeldahl Method [24], available P, K, Ca, Mg, S, Cu, Fe, Mn, $\mathrm{Zn}, \mathrm{B}$, and Na were determined using Mehlich-3 method [25], and cation exchange capacity (CEC) was determined by the ammonium acetate method $[22,26]$. The total soil $\mathrm{P}$ was determined by perchloric acid digestion using the Olsen and Sommers [27] method as cited in [28]. Exchangeable acidity was determined by leaching with potassium chloride $(\mathrm{KCl})$ followed by titration $[22,29,30]$. The general characteristics of the soil are presented in Table 1.

\subsection{Lime Rates and Phosphorus Fractionation}

2.3.1. Treatments and Experimental Design. A completely randomized design (CRD) was used to compute the experiment statistics. The experiment employed four lime rates in three replications. The amount of lime required was calculated according to the Shoemaker-McLean-Pratt (SMP) [31] method of lime recommendation. The SMP [31] singlebuffer procedure has been widely adopted and found to be particularly accurate for more acidic soils and frequently used in Ethiopia and in southern Ethiopia [16, 32]. The soil $\mathrm{pH}$ in the SMP buffer solution was 5.7, while it was 4.5 in water. This SMP single-buffer procedure uses a regression equation to calculate the required lime for different target $\mathrm{pH}$ values. In this case, the target $\mathrm{pH}$ in water was 6.5 and it was calculated by

$$
\operatorname{LR}(6.5)=1.867(\mathrm{pHB})^{2}-31.82(\mathrm{pHB})+131.23,
$$

where LR (6.5) is lime requirement to bring soil $\mathrm{pH}$ to 6.5 . $\mathrm{pHB}$ is the $\mathrm{pH}$ value by SMP buffer solution.

Thus, based on the calculation result, $10.5 \mathrm{t} / \mathrm{ha} \mathrm{CaCO}_{3}$ was used to bring the soil to the target $\mathrm{pH}$ (6.5 in water). Different rates were used as treatment, $0 \mathrm{t} / \mathrm{ha}(0 \%), 5.25 \mathrm{t} / \mathrm{ha}$ (50\%), $10.5 \mathrm{t} / \mathrm{ha}(100 \%)$, and $15.75 \mathrm{t} / \mathrm{ha}(150 \%) \mathrm{CaCO}_{3}$.

2.3.2. Phosphorus Fractionations. $100 \mathrm{~g}$ of soil was placed into $200 \mathrm{ml}$ polythene bags and each thoroughly mixed with equivalent weights of $100 \%$ pure fabricated lime rated as treatments $(0,50 \%, 100 \%$, and $150 \%$ of lime rate). The samples were incubated for 30 days [33] approximately at field water holding capacity by applying and maintaining $60 \%$ of the total amount of water which was required to saturate the soil based on laboratory analysis. At the end of the period, chemical properties of incubated soil such as $\mathrm{pH}$, $\mathrm{P}$ fractions, exchangeable bases, and acidity including some macro and microelements were measured.

The determination of $\mathrm{P}$ fractionation at different rates of lime followed the modified Chang and Jackson procedure as modified by [34]. In this procedure, the soil $\mathrm{P}$ is fractionated into soluble $\mathrm{P}$ ( $\mathrm{P}$-sol), aluminum bounded $\mathrm{P}(\mathrm{Al}-\mathrm{P})$, iron bounded $\mathrm{P}(\mathrm{Fe}-\mathrm{P})$, and calcium bounded $\mathrm{P}(\mathrm{Ca}-\mathrm{P})$, but the residual $\mathrm{P}$ (Res-P) was estimated by calculating the difference between the total $\mathrm{P}$ and the sum of all fractions of inorganic $\mathrm{P}$ including organic $\mathrm{P}$ [35]. The organic $\mathrm{P}$ was estimated by the Kaila-Virtanen procedure [36]. Phosphorus in the extracts was measured using the ascorbic acid molybdenum blue method [16] and the area-based soil $\mathrm{P}$ fractions $\left(\mathrm{kg} \mathrm{P} \mathrm{ha}^{-1}\right)$ were calculated using the concentrations of soil $\mathrm{P}$ fractions and soil bulk density data.

(1) Fractionation of Inorganic Phosphorus. According to [34], $1.00 \mathrm{~g}$ of soil was placed into a polypropylene $100 \mathrm{ml}$ centrifuge tube with $50 \mathrm{ml}$ of $1 \mathrm{~N} \mathrm{NH}_{4} \mathrm{Cl}$ and shaken for 


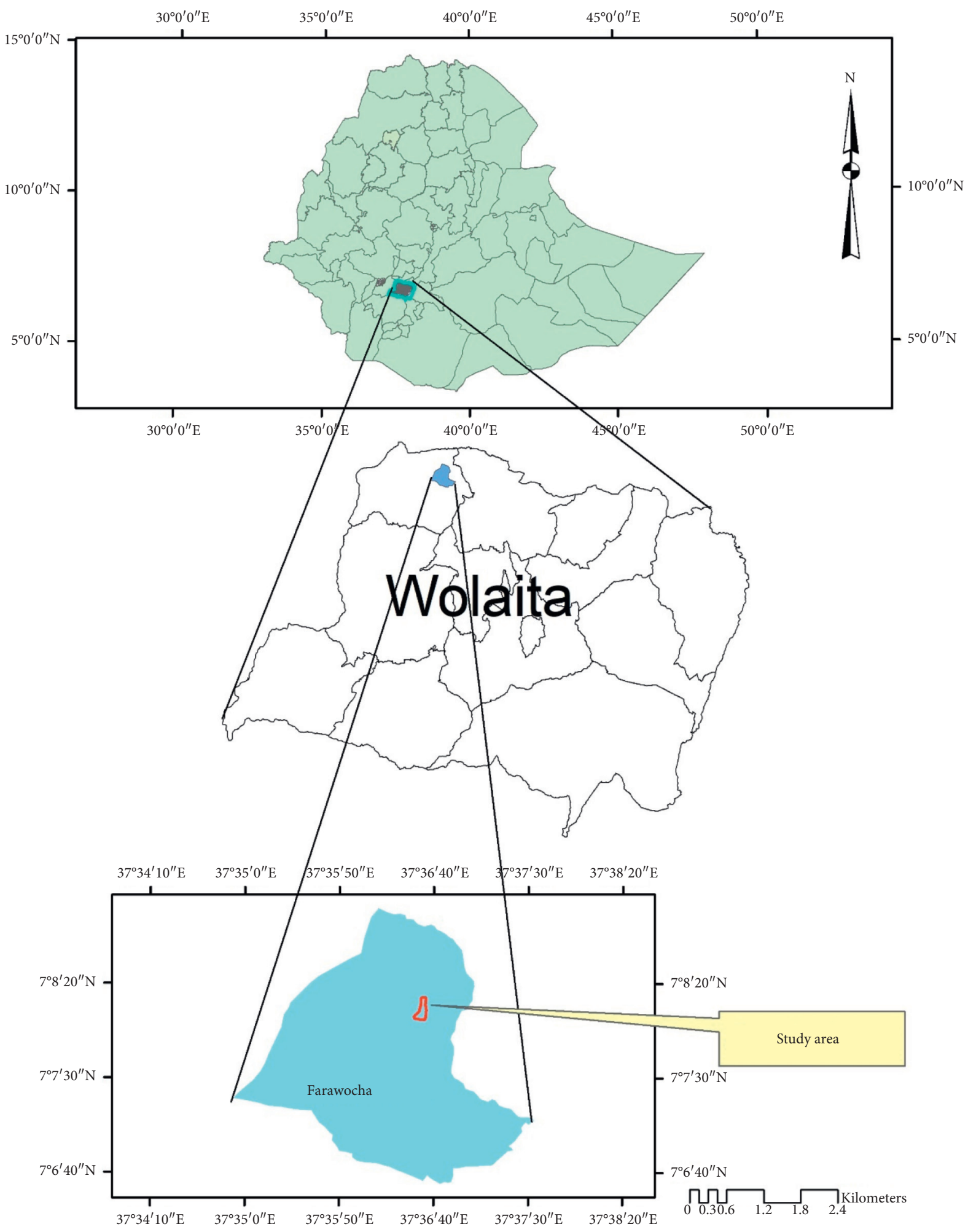

FIgURE 1: Map of the study area.

30 min to remove the easily soluble and loosely bound phosphorus (P-sol). The tube was centrifuged at 2,000 rpm for 10 minutes and the supernatant was reserved for spectrophotometer reading. To determine aluminum-associated $\mathrm{P}, 50 \mathrm{ml}$ of $0.5 \mathrm{~N} \mathrm{NH}_{4} \mathrm{~F}$, which was adjusted to $\mathrm{pH} 8.2$, was added to the residue from the previous extraction, shaken for $1 \mathrm{hr}$, and centrifuged for $10 \mathrm{~min}$ at 2,000 rpm. For the determination of $\mathrm{Fe}$-associated $\mathrm{P}$, the residue left from the extraction of Al-associated $\mathrm{P}$ was washed twice with $25 \mathrm{ml}$ portions of saturated $\mathrm{NaCl}$ by centrifuging at $2,000 \mathrm{rpm}$ for $5 \mathrm{~min}$ and then the decanted solution added to the $\mathrm{NH}_{4} \mathrm{~F}$ extract to make the volumetric flask to volume. 


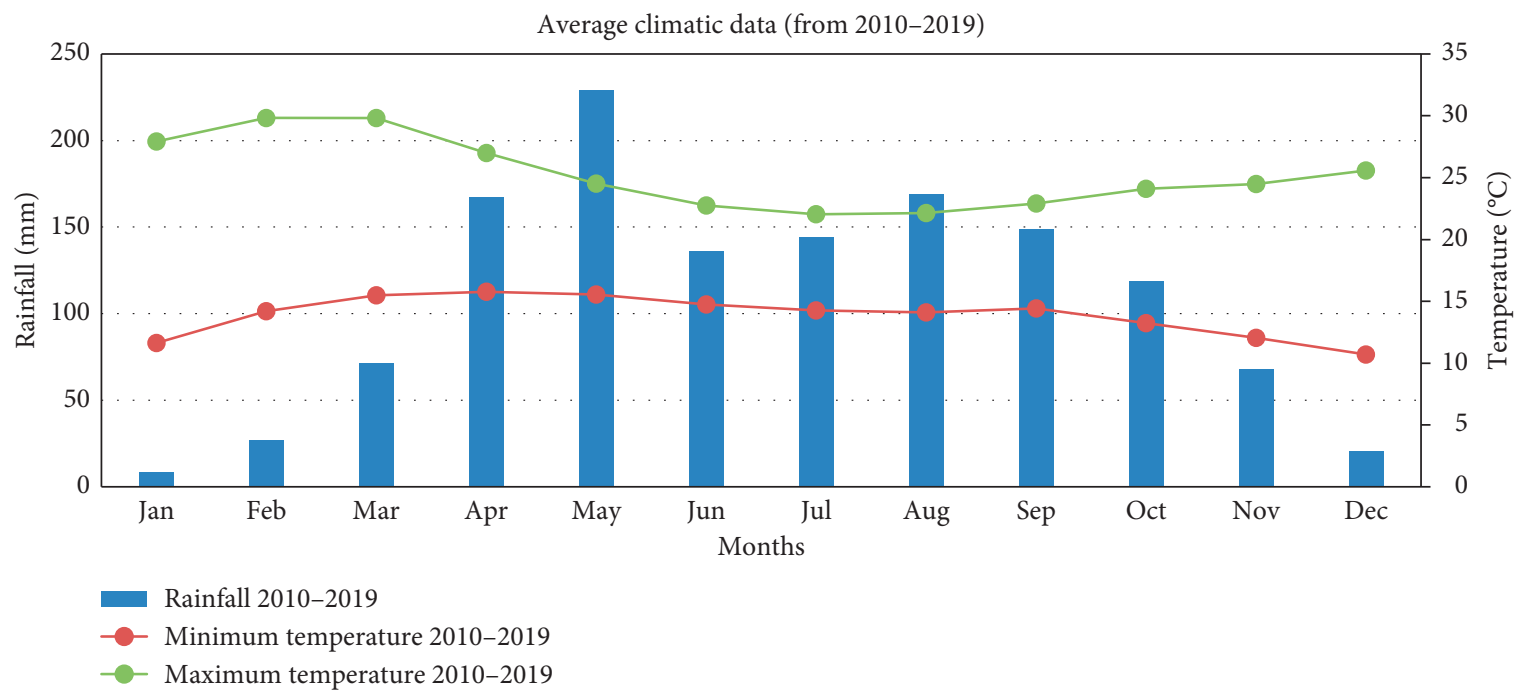

Figure 2: Climatic data of the study area (source: [17]).

TABLE 1: Surface soil characteristics before lime application.

\begin{tabular}{|c|c|c|}
\hline Parameter & Unit & Soil \\
\hline \multicolumn{3}{|l|}{ Soil particle size distribution } \\
\hline Sand & $\%$ & 24 \\
\hline Silt & $\%$ & 24 \\
\hline Clay & $\%$ & 52 \\
\hline Soil texture class & & Clay \\
\hline Bulk density & $\mathrm{g} / \mathrm{cm}^{3}$ & 1.2 \\
\hline $\mathrm{pH}\left(\mathrm{H}_{2} \mathrm{O}\right)$ & & 4.5 \\
\hline Electrical conductivity & $\mathrm{ms} / \mathrm{cm}$ & 0.06 \\
\hline Exchangeable acidity & $\mathrm{cmol}(+) / \mathrm{kg}$ & 4.2 \\
\hline $\mathrm{OC}$ & $\%$ & 2.44 \\
\hline $\mathrm{TN}$ & $\%$ & 0.17 \\
\hline Total P & $\mathrm{mg} / \mathrm{kg}$ & 357.5 \\
\hline Available P & $\mathrm{mg} / \mathrm{kg}$ & 3.2 \\
\hline Sulfur & $\mathrm{mg} / \mathrm{kg}$ & 29.5 \\
\hline $\mathrm{Ca}$ & $\mathrm{cmol}(+) / \mathrm{kg}$ & 2.44 \\
\hline $\mathrm{Mg}$ & $\mathrm{cmol}(+) / \mathrm{kg}$ & 0.33 \\
\hline K & $\mathrm{cmol}(+) / \mathrm{kg}$ & 0.67 \\
\hline $\mathrm{Na}$ & $\mathrm{cmol}(+) / \mathrm{kg}$ & 0.17 \\
\hline Ca saturation percentage & $\%$ & 16.7 \\
\hline $\mathrm{Mg}$ saturation percentage & $\%$ & 2.24 \\
\hline $\mathrm{K}$ saturation percentage & $\%$ & 4.6 \\
\hline $\mathrm{Na}$ saturation percentage & $\%$ & 1.2 \\
\hline Cation exchanging capacity & $\mathrm{cmol}(+) / \mathrm{kg}$ & 14.6 \\
\hline Percent base saturation & $\%$ & 24.7 \\
\hline Bo & $\mathrm{mg} / \mathrm{kg}$ & 0.39 \\
\hline $\mathrm{Fe}$ & $\mathrm{mg} / \mathrm{kg}$ & 179 \\
\hline $\mathrm{Ma}$ & $\mathrm{mg} / \mathrm{kg}$ & 199 \\
\hline $\mathrm{Cu}$ & $\mathrm{mg} / \mathrm{kg}$ & 0.66 \\
\hline $\mathrm{Zn}$ & $\mathrm{mg} / \mathrm{kg}$ & 4.04 \\
\hline
\end{tabular}

Then, $50 \mathrm{ml}$ of $0.1 \mathrm{~N} \mathrm{NaOH}$ was added, shaken for $17 \mathrm{hrs}$, and centrifuged for $15 \mathrm{~min}$ at 2,400 rpm and the decanted solution was reserved after it was made to volume with saturated $\mathrm{NaCl}$ after washing and centrifuging similarly as described above and the residue left for calcium-associated $\mathrm{P}$ extraction. $50 \mathrm{ml}$ of $0.5 \mathrm{~N} \mathrm{H}_{2} \mathrm{SO}_{4}$ was added, shaken for $1 \mathrm{hr}$, and then centrifuged for $10 \mathrm{~min}$ at $2,000 \mathrm{rpm}$. The washing procedure with saturated $\mathrm{NaCl}$ was done as described above.
(2) Fractionation of Organic Phosphorus. To determine Org-P, the Kaila-Virtanen procedure was used. Accordingly, Org-P was determined by subtracting $\mathrm{P}$ found in an unignited soil sample from ignited soil samples after digestion with $4 \mathrm{~N} \mathrm{H}_{2} \mathrm{SO}_{4}$. One gram of soil $(<0.5 \mathrm{~mm})$ was ignited in a muffle furnace at $550^{\circ} \mathrm{C}$ for $2 \mathrm{~h}$, with a gradual increase to the targeted temperature during the first hour, and then the temperature was maintained at $550^{\circ} \mathrm{C}$ for the last $1 \mathrm{~h}$. After cooling, the ignited sample was digested by shaking with $30 \mathrm{ml}$ of $4 \mathrm{~N} \mathrm{H}_{2} \mathrm{SO}_{4}$ for $4 \mathrm{~h}$ and centrifuged for $10 \mathrm{~min}$ at $2,000 \mathrm{rpm}$. The unignited soil sample was also digested, shaken, and centrifuged similarly to the ignited sample [36] and then the difference between measured $\mathrm{P}$ from unignited soil sample and ignited soil sample was calculated as Org-P. The residual $\mathrm{P}$ was calculated as the difference between total $\mathrm{P}$ and total extracted $\mathrm{P}$ (Org-P, Al-P, Fe-P, and Ca-P) [37].

2.4. Statistical Data Analysis. Data were subjected to analysis of variance (ANOVA) following the standard procedure using Statistix version 8.0 software as described by [38]. Mean separation was done using least significant difference (LSD) at $5 \%$ of probability level whenever significant differences among treatment means were detected. In addition, descriptive statistics and Pearson correlation analysis were performed.

\section{Result and Discussion}

3.1. Phosphorus Fractions as Influenced by Liming Rates. All the $\mathrm{P}$ fractions significantly $(p<0.05)$ respond to lime application. The $\mathrm{P}$ pool in their increasing proportion in soil was Org-P $>$ Res- $\mathrm{P}>\mathrm{Fe}-\mathrm{P}>\mathrm{Al}-\mathrm{P}>\mathrm{Ca}-\mathrm{P}>\mathrm{P}$-sol. This result is similar to the report in [14].

3.1.1. Soluble Phosphorus (P-sol). P-sol was the smallest of all $\mathrm{P}$ fractions and it was significantly $(p<0.05)$ affected by liming. It increased with increasing rates of lime from $3.13(0 \%$ lime) to $4.28 \mathrm{mg} / \mathrm{kg}$ ( $150 \%$ lime) (Table 2 ; Figure 3$)$. It also 
TABLE 2: Effects of lime on phosphorus fractions (mean and percentage in brackets).

\begin{tabular}{|c|c|c|c|c|c|c|}
\hline Lime rate $(\mathrm{t} / \mathrm{ha})$ & P_sol & \multicolumn{4}{|c|}{$(\mathrm{mg} / \mathrm{kg})$} & Org_P \\
\hline & 3.13 c $(0.88)$ & $23.61 \mathrm{a}(6.61)$ & 9.97 a (2.79) & 6.06 c (1.70) & $35.54 \mathrm{c}(9.94)$ & 279.18 a (78.09) \\
\hline 5.25 & 3.67 b (1.03) & $11.73 \mathrm{~b}(3.281)$ & $6.74 \mathrm{~b}(1.89)$ & $7.31 \mathrm{~b}(2.04)$ & $67.20 \mathrm{~b}(18.80)$ & $260.85 \mathrm{~b}(72.97)$ \\
\hline 10.5 & $3.85 \mathrm{ab}(1.08)$ & $10.32 \mathrm{~b}(2.89)$ & 6.16 c (1.72) & $9.48 \mathrm{a}(2.65)$ & $74.08 \mathrm{~b}(20.72)$ & $253.61 \mathrm{~b}(70.94)$ \\
\hline 15.75 & $4.28 \mathrm{a}(1.2)$ & $9.80 \mathrm{~b}(2.74)$ & $2.93 \mathrm{~d}(0.82)$ & 9.79 a (2.74) & 104.80 a $(29.31)$ & 225.90 c (63.19) \\
\hline LSD 0.05 & 0.52 & 2.63 & 0.48 & 1.13 & 17.7 & 14.86 \\
\hline $\mathrm{CV} \%$ & 6.98 & 9.50 & 3.71 & 6.93 & 12.58 & 2.92 \\
\hline
\end{tabular}

LSD (0.05): least significant difference at the $5 \%$ level; CV: coefficient of variation. Means in a column followed by the same letters are not significantly different at the $5 \%$ level of significance.

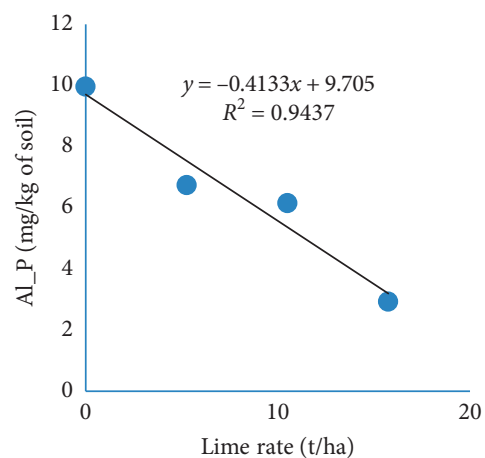

(a)

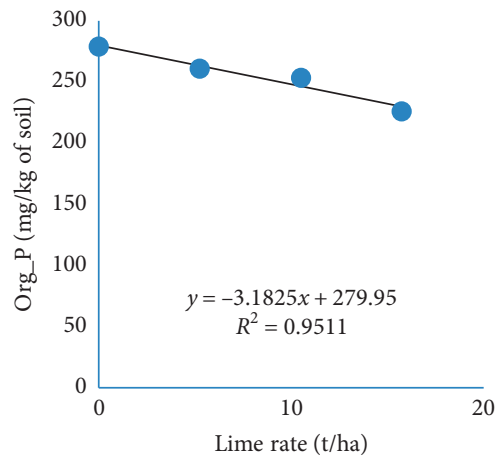

(d)

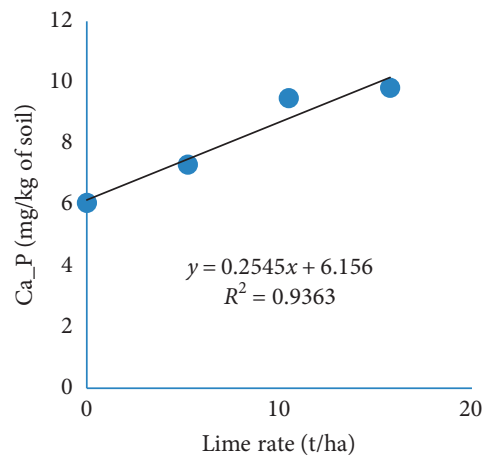

(b)

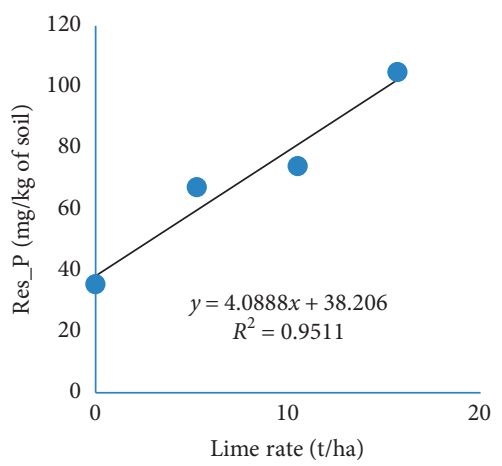

(e)

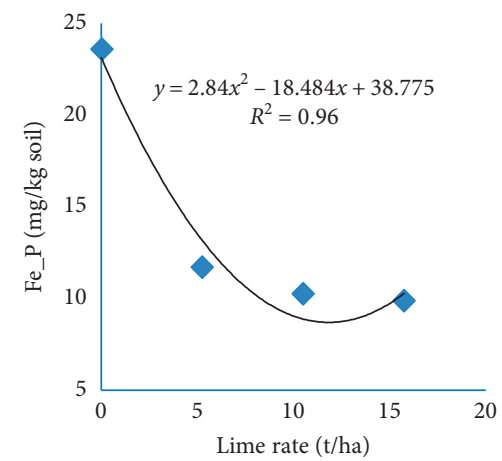

(c)

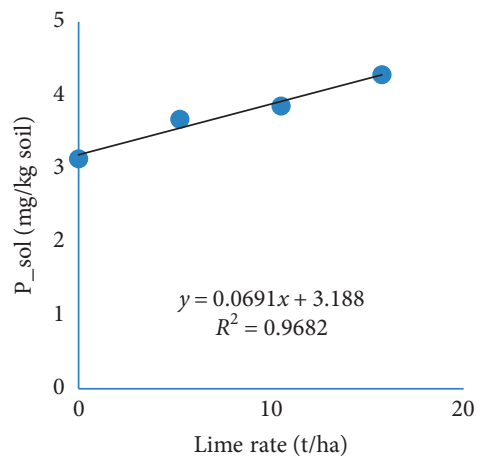

(f)

Figure 3: Effects of lime on (a) Al_P, (b) Ca_P, (c) Fe_P, (d) Org_P, (e) Res_P, and (f) P_sol.

showed positive relationship with lime $\left(r=0.88^{* * *}\right)$ (Table 3$)$. Out of the total P, P-sol accounted for 0.88 to $1.2 \%$ (Table 2) and weighted 7.51 (no lime) to $10.27 \mathrm{~kg} \mathrm{ha}^{-1}$ (150\% lime). Reference [39] rated the P-sol (Olsen P) $<15 \mathrm{mg} / \mathrm{kg}$ as low and $>30 \mathrm{mg} / \mathrm{kg}$ as extremely high. For the soils of the study area, it considered $<36 \mathrm{~kg} \mathrm{ha}^{-1}$ as low and $>72 \mathrm{~kg} \mathrm{ha}^{-1}$ as extremely high. Overall, lime resulted in more P-sol to the plant, yet it was not enough to meet the requirement by the plant even at a $150 \%$ lime rate. Thus, the soil should be supported by other soil management practices and external P fertilizers.

3.1.2. Iron-Associated Phosphorus (Fe-P). Among inorganic $\mathrm{P}$ fractions, Fe-P was the highest ranging from $23.61 \mathrm{mg} / \mathrm{kg}$ (unlimed) to $9.80 \mathrm{mg} / \mathrm{kg}$ (150\% lime) and accounted for 6.61 to $2.74 \%$ of total $\mathrm{P}$ (Table 2). Its content significantly declined with increasing lime dose $\left(r=-0.83^{* * *}\right)$ (Table 3; Figure 3 ). Through hydrolysis reaction of oxides and hydroxides of $\mathrm{Al}$ and $\mathrm{Fe}$, the released $\mathrm{H}^{+}$lowered the soil $\mathrm{pH}$ and produced higher extractable Fe. Protonation in the soil with decreasing $\mathrm{pH}$ decreases the negative charge and increases the attraction to a positively charged surface [40]. As a result, the $\mathrm{Fe}$-associated $\mathrm{P}$ was found to be relatively high [41]. But, with increased $\mathrm{pH}$ due to applied lime, Fe became insoluble and its activity was replaced by $\mathrm{Ca}^{+2}$; then the $\mathrm{P}$ held by Fe decreased [42]. The changes in ionic composition due to changes in soil $\mathrm{pH}$ lead to a shift in chemical equilibria by increasing concentrations of dissolved $\mathrm{Ca}^{+2}$ and displaced hydrolytic Fe that can decrease the availability of $\mathrm{P}$ in the soil solution [43]. The decrease in Fe-P could be due to their precipitation as insoluble $\mathrm{Fe}(\mathrm{OH})^{3}$ after the increased addition of liming material. Fe oxides become 
TABLE 3: Correlation (Pearson) of lime with phosphorus fractions.

\begin{tabular}{lccccc}
\hline & Lime & Al_P & Ca_P & Fe_P & Org_P \\
\hline Al_P & $-0.97^{* * *}$ & & & & \\
Ca_P & $0.92^{* * *}$ & $-0.83^{* * *}$ & & \\
Fe_P & $-0.83^{* * *}$ & $0.85^{* * *}$ & $-0.78^{* *}$ & $0.79^{* *}$ & $-0.86^{* * *}$ \\
Org_P & $-0.93^{* * *}$ & $0.96^{* * *}$ & $-0.79^{* *}$ & $-0.99^{* * *}$ \\
Res_P & $0.94^{* * *}$ & $-0.97^{* * *}$ & $0.80^{* *}$ & $-0.84^{* * *}$ \\
P_sol & $0.88^{* * *}$ & $-0.88^{* * *}$ & $0.78^{* *}$ & $-0.79^{* * *}$ & $0.86^{* * *}$ \\
\hline
\end{tabular}

${ }^{*}$ Significance at the $5 \%$ level; ${ }^{* *}$ significance at the $1 \%$ level; ${ }^{* * *}$ significance at the $0.1 \%$ level. NS: not significant.

TABLE 4: Effects of lime on soil pH and exchangeable acidity.

\begin{tabular}{lcc}
\hline Lime rate $(\mathrm{t} / \mathrm{ha})$ & $\mathrm{pH}\left(\mathrm{H}_{2} \mathrm{O}\right)$ & Exchangeable acidity $(\mathrm{cmol}(+) / \mathrm{kg})$ \\
\hline 0 & $4.55 \mathrm{~d}$ & $4.18 \mathrm{a}$ \\
5.25 & $5.38 \mathrm{c}$ & $0.73 \mathrm{~b}$ \\
10.5 & $6.09 \mathrm{~b}$ & $0.23 \mathrm{c}$ \\
15.75 & $6.60 \mathrm{a}$ & $0.23 \mathrm{c}$ \\
LSD 0.05 & 0.04 & 0.11 \\
CV \% & 0.38 & 4.10 \\
\hline
\end{tabular}

LSD 0.05: least significant difference at the $5 \%$ level; CV: coefficient of variation. Means in the column followed by the same letters are not significantly different at the $5 \%$ level of significance.

more negatively charged with an increase in $\mathrm{pH}$ contributing to an increase in available $\mathrm{P}$. Therefore, Fe bound $\mathrm{P}$ decreased as $\mathrm{pH}$ increased [44].

3.1.3. Aluminum-Associated Phosphorus (Al-P). Al-P was the second-highest inorganic $\mathrm{P}$ fraction following Fe-P. It was affected significantly by lime $(p<0.05)$ with a correlation coefficient value of $-0.97^{* * *}$. The Al-P ranged from 9.97 to $2.93 \mathrm{mg} / \mathrm{kg}$ for unlimed to $150 \%$, respectively (Table 2; Figure 3). In proportion, it decreased from 2.79 to $0.82 \%$ (Table 2). In acidic soil, Al-P is higher than P-sol due to the content and reactivity of oxides, hydroxides, and oxyhydroxides of $\mathrm{Al}[45,46]$. Thus, the replacement of soluble $\mathrm{Al}^{3+}$ by $\mathrm{Ca}^{2+}$ on the exchanging site and precipitation of soluble $\mathrm{Al}^{3+}$ with the hydroxyl anions generated by carbonate hydrolysis in the soil solution from applied lime [47] might be due to the decreased level of Al-P with increasing rates of lime.

3.1.4. Calcium-Associated Phosphorus (Ca-P). The Ca-P increased with the application of lime from 6.06 (unlimed) to $9.79 \mathrm{mg} / \mathrm{kg}(150 \%$ lime) which accounts for $1.70 \%$ to $2.74 \%$ (Table 2) and correlated positively with lime $\left(r=0.92^{* * *}\right)$ (Table 3; Figure 3). It also weighed between 14.5 and $23.5 \mathrm{~kg} \mathrm{ha}^{-1}$. Even in acidic soil, Ca has an effect on the fixation of $\mathrm{P}$; therefore, the application of lime increases soil $\mathrm{pH}$ and $\mathrm{Ca}$, and, as a result, $\mathrm{Ca}-\mathrm{P}$ increased $[16,48]$.

3.1.5. Residual Phosphorus (Res-P). The value of Res-P was between $35.5 \mathrm{mg} / \mathrm{kg}(0 \%)$ and $104.8 \mathrm{mg} / \mathrm{kg}$ (150\%) (Table 2) and constituted 9.94 to $29.31 \%$ of the total $\mathrm{P}$ and correlated positively with the lime $\left(r=0.94^{* * *}\right)$ (Table 3$)$. It was the second-largest $\mathrm{P}$ fraction after Org-P. The Res-P fraction, which is mainly composed of insoluble and stable forms of $\mathrm{P}$, such as $\mathrm{Ca}-, \mathrm{Fe}-$, and Al-bounded $\mathrm{P}$, represents the unavailable forms of $\mathrm{P}$ pools in the soil. The increment of Res-P with increased rates of lime (Figure 3 ) can be due to the immediate complexation and reaction of both organic and inorganic released $\mathrm{P}$ with the surface of the clay [49-51]. Surface adsorption, so-called ligand exchange, and surface complexation [52] would be the mechanisms for the complexation of released $\mathrm{P}$ with the clay surface.

3.1.6. Organic Phosphorus (Org-P). Organic $\mathrm{P}$ was found to be the highest among $\mathrm{P}$ fractions which ranges from $279(0 \%$ lime) to $226 \mathrm{mg} / \mathrm{kg}$ (150\% lime) (Table 2) and accounted for 78.1 to $63.2 \%$ of the total $\mathrm{P}$ and correlated negatively $\left(r=-0.93^{* * *}\right)$ (Table 3$)$. In weight bases, it weighted between 670 and $542 \mathrm{~kg} \mathrm{ha}^{-1}$. The organic form of $\mathrm{P}$ is a significant and relevant source of soil $\mathrm{P}$ and contributes to the increase in available $\mathrm{P}$ (labile P) $[53,54]$.

From the total of soil $\mathrm{P}, 15-80 \%$ occurs in the organic form [55-57]. An increase in lime rate resulted in a significant decrease in the Org-P fraction $(p<0.05)$. The organic materials remained in the soil and the microbial mass may result in the Org-P to be the highest among others. This can be due to the increased activity of microorganisms in the improved environment by the application of lime. The microbes start to decompose and release $\mathrm{P}$ from organic material to the soil once the environment becomes conducive with the application of lime [58]. As a result, the amount of $\mathrm{P}$ held by organic material will be decreased [49].

3.1.7. Total Phosphorus. The value of total $\mathrm{P}$ recorded in the studied soil was $357.5 \mathrm{mg} / \mathrm{kg}$, which was below the concentration reported by [16]. This may be due to the nature and the status of exploitation of the soils. 


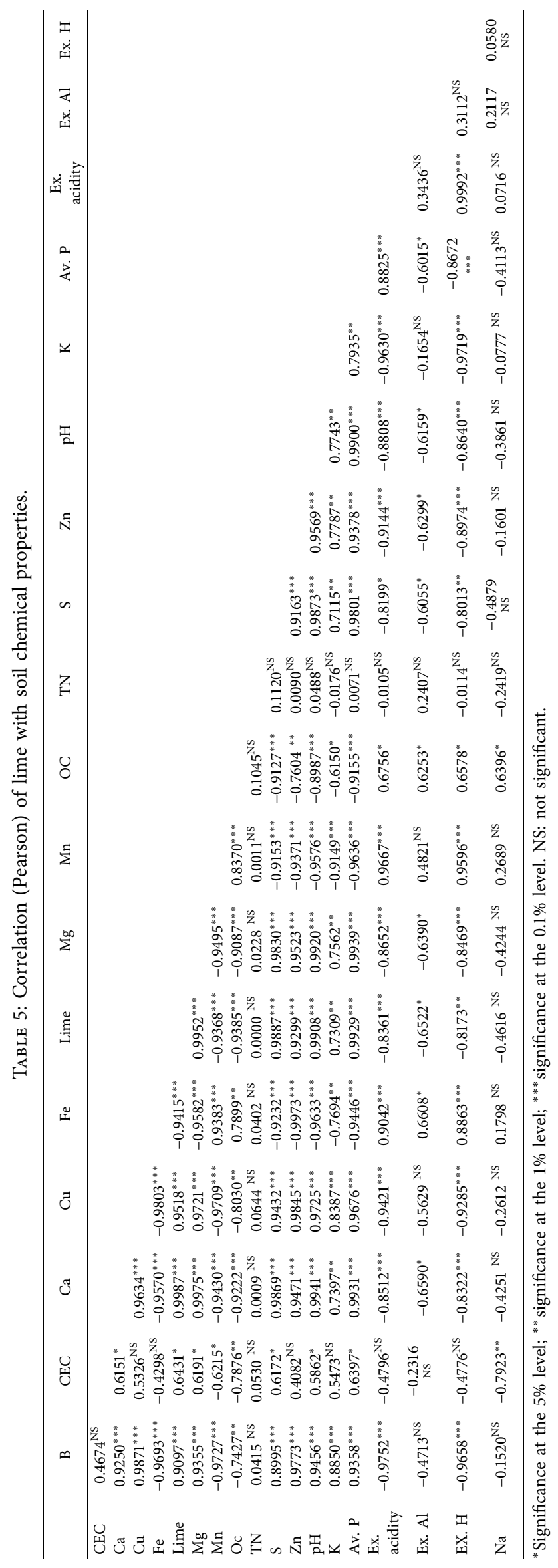


TABLE 6: Effects of lime on soil available P, S, TN, and \%OC (mean).

\begin{tabular}{|c|c|c|c|c|}
\hline Lime rate $(\mathrm{t} / \mathrm{ha})$ & Ava. P & $S$ & TN & OC \\
\hline 0 & $3.2 \mathrm{~d}$ & $29.54 \mathrm{~d}$ & $0.17 \mathrm{a}$ & $2.44 \mathrm{a}$ \\
\hline 5.25 & $4.53 \mathrm{c}$ & $34.19 \mathrm{c}$ & $0.17 \mathrm{a}$ & $2.41 \mathrm{~b}$ \\
\hline 10.5 & $5.36 \mathrm{~b}$ & $39.06 \mathrm{~b}$ & $0.17 \mathrm{a}$ & $2.39 \mathrm{c}$ \\
\hline 15.75 & $6.32 \mathrm{a}$ & $44.04 \mathrm{a}$ & $0.17 \mathrm{a}$ & $2.31 \mathrm{~d}$ \\
\hline LSD 0.05 & 0.19 & 1.15 & 0.02 & 0.02 \\
\hline $\mathrm{CV} \%$ & 1.96 & 1.57 & 5.09 & 0.42 \\
\hline
\end{tabular}

LSD 0.05: least significant difference at the $5 \%$ level; CV: coefficient of variation. Means in the column followed by the same letters are not significantly different at the $5 \%$ level of significance.

TABLE 7: Effects of lime on soil basic cations and CEC (mean).

\begin{tabular}{|c|c|c|c|c|c|}
\hline Lime rate $(\mathrm{t} / \mathrm{ha})$ & $\mathrm{Ca}$ & $\mathrm{Mg}$ & $\begin{array}{c}\mathrm{K} \\
\mathrm{cmol}(+) / \mathrm{kg} \text { soil }\end{array}$ & $\mathrm{Na}$ & CEC \\
\hline 0 & $2.44 \mathrm{~d}$ & $0.33 \mathrm{~d}$ & $0.65 \mathrm{~d}$ & $0.169 \mathrm{a}$ & $14.58 \mathrm{~b}$ \\
\hline 5.25 & $7.94 \mathrm{c}$ & $0.47 \mathrm{c}$ & $0.79 \mathrm{a}$ & $0.173 \mathrm{a}$ & $16.09 \mathrm{~b}$ \\
\hline 10.5 & $13.8 \mathrm{~b}$ & $0.62 \mathrm{~b}$ & $0.77 \mathrm{c}$ & $0.176 \mathrm{a}$ & $14.73 \mathrm{~b}$ \\
\hline 15.75 & $18.3 \mathrm{a}$ & $0.72 \mathrm{a}$ & $0.79 \mathrm{~b}$ & $0.155 \mathrm{~b}$ & $17.99 \mathrm{a}$ \\
\hline LSD 0.05 & 5.19 & 3.05 & 2.64 & 2.77 & 1.9 \\
\hline $\mathrm{CV} \%$ & 0.12 & 2.38 & 0.44 & 3.58 & 5.99 \\
\hline
\end{tabular}

LSD 0.05: least significant difference at the 5\% level; CV: coefficient of variation. Means in a column followed by the same letters are not significantly different at the $5 \%$ level of significance.

3.2. Effects of Lime on Chemical Properties. Significant $(p<0.05)$ increase in soil $\mathrm{pH}$ and a decrease in exchangeable acidity were recorded with the application of lime (Table 4). Soil pH significantly correlated with $r$ value of $0.99^{* * *}$ and increased from 4.5 to 6.6 but exchangeable acidity decreased from 4.18 to $0.23 \mathrm{cmol}(+) / \mathrm{kg}$ soil and negatively correlated with lime $\left(r=-0.84^{* * *}\right)$ (Table 5). Decreasing the content of exchangeable $\mathrm{Al}^{3+}$ and its precipitation with the hydroxyl anion through the replacement of $\mathrm{Ca}^{2+}$ from carbonate hydrolysis, the value of $\mathrm{pH}$ increased, and exchangeable acidity decreased $[47,48]$.

Lime also influenced $(p<0.05)$ OC, as well as available $\mathrm{P}$ and S (Table 6). Available P and S increased and correlated positively with increased lime (both $r=0.99^{* * *}$ ) and increased with liming from 3.2 to $6.32 \mathrm{mg} / \mathrm{kg}$ and 29.54 to $44.04 \mathrm{mg} / \mathrm{kg}$, respectively. OC decreased from 2.44 to $2.31 \%$ and negatively correlated with increased lime $\left(r=-0.94^{* * *}\right)$ (Tables 5 and 6). The increased available $P$ with an increased rate of lime can be due to the $\mathrm{P}$ released from $\mathrm{Al}$ and $\mathrm{Fe}$ because of improved $\mathrm{pH}$ by applied lime $[59,60]$. Soil OC was decreased because of the decomposition of organic matter in the soil with an improved environment for the activities of microorganisms by the effect of lime [44]. Moreover, the OC increased with the increased lime application but decreased with respiration rate per unit biomass [61-63]. Sulfur also increased significantly with an increased rate of lime $(p<0.05)$ (Table 6). According to [60], $\mathrm{S}$ increased with increased lime rates because of the $\mathrm{pH}$ change and easy dissociation of organic matter by the microbial and biochemical attack and the consequent mineralization of $\mathrm{S}$ from the organic pool due to applied lime. Reduction in acidity because of change in $\mathrm{pH}$ with the application of lime increased the activity of microbes and increased $\mathrm{N}$ mineralization [44] but, with increased rates of
TABle 8: Effects of lime on Fe, Mn, Cu, Zn, and B (mean).

\begin{tabular}{|c|c|c|c|c|c|}
\hline $\begin{array}{l}\text { Lime rate }(\mathrm{t} / \\
\mathrm{ha})\end{array}$ & $\mathrm{Fe}$ & $\mathrm{Mn}$ & $\begin{array}{l}\mathrm{Cu} \\
\mathrm{mg} /\end{array}$ & $/ \mathrm{kg}$ & B \\
\hline 0 & $\begin{array}{c}178.69 \\
\mathrm{a}\end{array}$ & $198.78 \mathrm{a}$ & $0.66 c$ & $4.04 \mathrm{~d}$ & $0.39 \mathrm{c}$ \\
\hline 5.25 & $\begin{array}{c}156.61 \\
\mathrm{~b}\end{array}$ & $\begin{array}{c}167.17 \\
\mathrm{~b}\end{array}$ & $\begin{array}{c}0.79 \\
b\end{array}$ & $4.30 \mathrm{c}$ & $0.47 \mathrm{~b}$ \\
\hline 10.5 & $129.82 \mathrm{c}$ & $159.84 \mathrm{c}$ & $0.88 \mathrm{a}$ & $4.60 \mathrm{a}$ & $0.51 \mathrm{a}$ \\
\hline 15.75 & $130.60 \mathrm{c}$ & $\begin{array}{c}150.16 \\
\mathrm{~d}\end{array}$ & $0.90 \mathrm{a}$ & $4.57 \mathrm{~b}$ & $0.51 \mathrm{a}$ \\
\hline LSD 0 . & 2.99 & 3.33 & 0.02 & $9.989 E-03$ & $9.989 E-03$ \\
\hline $\mathrm{CV} \%$ & 1.01 & 0.99 & 1.47 & 0.11 & 1.06 \\
\hline
\end{tabular}

LSD 0.05: least significant difference at the $5 \%$ level; CV: coefficient of variation. Means in the column followed by the same letters are not significantly different at the $5 \%$ level of significance.

lime, the microorganism activities and their increased population by the effect of lime could also be the reason for $\mathrm{N}$ immobilization [64]. This can explain the reason for the change in $\mathrm{N}$ in these acidic nitisols (Table 6).

The increasing lime rates ( $0 \%$ to $150 \%)$ increased $\mathrm{Ca}, \mathrm{Mg}$, and $\mathrm{K}$ contents with positive correlation values of $0.99^{* * *}$, $0.99^{* * *}$, and $0.73^{* *}$, respectively (Tables 5 and 7 ), while the exchangeable $\mathrm{Na}$ and CEC showed no significant response for the applied lime. The finding was in agreement with [59] which reported that $\mathrm{Na}$ was not affected by the lime application. As reported by $[65,66]$ and [67], the application of lime increased $\mathrm{Ca}, \mathrm{Mg}$, and $\mathrm{K}$ contents. This is due to the increased base saturation as a result of $\mathrm{pH}$ change induced by lime application [59].

Copper, $\mathrm{Zn}$, and B increased with increased lime rate; on the other hand, $\mathrm{Fe}$ and $\mathrm{Mn}$ contents were reduced (Table 8). Due to increase in $\mathrm{pH}$ by the application of lime, amounts of metal organic complexes of $\mathrm{Cu}$ steadily decreased; a two-fold 
increase of OC content nearly doubled the share of $\mathrm{Cu}$ from organic matter in the total concentration of $\mathrm{Cu}$ in soil solution $[68,69]$. In line with this study, the reports of $[48,70]$ stated that the significant reduction in Fe and Mn was due to increased lime application that makes iron and $\mathrm{Mn}$ be insoluble and replaced by $\mathrm{Ca}^{+2}$ ions found in lime $[42,71]$.

\section{Conclusion}

In this study, the fractions of $\mathrm{P}$ were identified and quantified and the effect of lime rates on $\mathrm{P}$ fractions and chemical properties were investigated. The result showed Org-P to be the largest among the fractions. Among inorganic $\mathrm{P}$ fractions, Fe-P was higher than Al-P and $\mathrm{Ca}-\mathrm{P}$, whereas $\mathrm{P}$-sol was observed to be the smallest fraction. The application of lime significantly influenced the $\mathrm{P}$ pool and its availability. Liming resulted to be significantly and positively correlated with $\mathrm{P}$-sol, $\mathrm{Ca}-\mathrm{P}$, and Res-P but a negative correlation was observed with Fe-P, Al-P, and Org-P $(p<0.05)$. Although the effect of lime enhanced the level of $\mathrm{P}$-sol, the change was not found to be enough to satisfy the need of the plant even at $150 \%$. This showed that the study soil was originally poor in available $\mathrm{P}$. The soil $\mathrm{pH}$ markedly affected most of the chemical properties and the lime application significantly changed the $\mathrm{pH}$ and mitigated the status of essential nutrient elements. Therefore, liming of these acidic nitisols at $100 \%$ is suggested because the changes in most of the chemical properties due to applied lime, especially the P-sol, were not significant between 100 and 150\% lime rates. It is concluded that application of external fertilizer is suggested to meet the $\mathrm{P}$ requirement of the plant. In addition, assessing the $\mathrm{P}$ dynamics under field condition, long period of incubation, or concurrent use of other soil management practices is suggested.

\section{Data Availability}

The data used to support the findings of this study are available from the corresponding author upon request.

\section{Conflicts of Interest}

The authors declare that there are no conflicts of interest.

\section{Authors' Contributions}

The authors collected, analyzed, interpreted, and prepared the manuscript.

\section{Acknowledgments}

The authors acknowledge Wolaita Sodo University for funding this research.

\section{References}

[1] L. De Wispelaere, V. Marcelino, A. Regassa et al., "Revisiting nitic horizon properties of Nitisols in SW Ethiopia," Geoderma, vol. 243-244, pp. 69-79, 2015.
[2] E. Elias, "Characteristics of Nitisol profiles as affected by land use type and slope class in some Ethiopian highlands," Environmental Systems Research, vol. 6, no. 20, pp. 1-15, 2017.

[3] A. Melese, H. Gebrekidan, Y. H. Markku, and Y. Birru, "Phosphorus status, inorganic phosphorus forms, and other physicochemical properties of acid soils of Farta district, northwestern highlands of Ethiopia," Applied and Environmental Soil Science, vol. 2015, Article ID 748390, 11 pages, 2015.

[4] E. U. C. d. Costa, J. K. S. Araujo, L. V. d. M. W. Neves et al., "Genesis and classification of nitisols from volcano-sedimentary lithology in northeastern Brazil," Revista Brasileira de Ciência Do Solo, vol. 43, pp. 1-17, 2019.

[5] A. Abdolzadeh, X. Wang, E. J. Veneklaas, and H. Lambers, "Effects of phosphorus supply on growth, phosphate concentration and cluster-root formation in three lupinus species," Annals of Botany, vol. 105, no. 3, pp. 365-374, 2009.

[6] S. Verma, S. K. Subehia, and S. P. Sharma, "Phosphorus fractions in an acid soil continuously fertilized with mineral and organic fertilizers," Biology and Fertility of Soils, vol. 41, no. 4, pp. 295-300, 2005.

[7] A. Kwabiah, N. Stoskopf, C. Palm, and R. Voroney, "Soil P availability as affected by the chemical composition of plant materials: implications for P-limiting agriculture in tropical Africa," Agriculture, Ecosystems and Environment, vol. 100, no. 1, pp. 53-61, 2003.

[8] A. Bekele, K. Kibret, B. Bedadi, M. Yli-Halla, and T. Balemi, "Effects of lime, vermicompost, and chemical P fertilizer on selected properties of acid soils of Ebantu district, western highlands of Ethiopia," Applied and Environmental Soil Science, vol. 2018, no. 1, 13 pages, Article ID 8178305, 2018.

[9] F. Laekemariam and K. Kibret, "Explaining soil fertility heterogeneity in smallholder farms of southern Ethiopia," Applied and Environmental Soil Science, vol. 2020, no. 15, pp. 1-16, 2020.

[10] W. Ahmed, H. Jing, L. Kaillou et al., "Changes in phosphorus fractions associated with soil chemical properties under longterm organic and inorganic fertilization in paddy soils of southern China," PLoS One, vol. 14, no. 5, pp. 1-17, 2019.

[11] M. Chandrakala, C. A. Srinivasamurthy, V. R. R. Parama, S. Bhaskar, K. Sanjeev, and D. V. Naveen, "Phosphorus fractions-keys to soil based P management," International Journal of Current Microbiology and Applied Sciences, vol. 6, no. 11, pp. 281-294, 2017.

[12] S. C. Appelhans, P. A. Barbagelata, R. J. M. Melchiori, and F. G. Boem, "Assessing soil P fractions changes with longterm phosphorus fertilization related to crop yield of soybean and maize," Soil Use and Management, vol. 36, no. 3, pp. 524-535, 2020.

[13] Y. Xiaoyan, C. Xiangwei, and Y. Xitian, "Phosphorus release kinetics and solubility capacity of phosphorus fractionation induced by organic acids from a black soil in northeast China," Canadian Journal of Soil Science, vol. 99, no. 1, pp. 92-99, 2019.

[14] T. I. Shah, A. P. Rai, and M. A. Aziz, "Relationship of phosphorus fractions with soil properties in mothbean growing acid soils of north western Indian himalayas," Communications in Soil Science And Plant Analysis, vol. 50, no. 9, pp. 1192-1198, 2019.

[15] X. Wang, R. S. Yost, and B. A. Linquist, "Soil aggregate size affects phosphorus desorption from highly weathered soils and plant growth," Soil Science Society of America Journal, vol. 65, no. 1, pp. 139-146, 2001. 
[16] A. Kifu, S. Beyene, and J. Schoenau, "Fractionation and availability of phosphorus in acid soils of Hagereselam, southern Ethiopia under different rates of lime," Chemical and Biological Technologies in Agriculture, vol. 4, no. 1, pp. 1-7, 2017.

[17] PDAV (Power Data Access Viewer), "NASA," 2020, https:// power.larc.nasa.gov/data-access-viewer/.

[18] FAO (Food and Agriculture Organization), Guidelines for Soil Description, Food and Agriculture Organization of the United Nations, Rome, Italy, 4th edition, 2006.

[19] G. J. Bouyoucos, "Hydrometer method improved for making particle size analyses of soils," Agronomy Journal, vol. 54, no. 5, pp. 464-465, 1962.

[20] L. P. Van Reeuwijk, Procedures for Soil Analysisp. 34, 3rd edition, International Soil Reference and Information Center (ISRIC), Wageningen, Netherlands, 1992.

[21] A. A. G. Al-Shammary, A. Z. Kouzani, A. Kaynak, S. Y. Khoo, M. Norton, and W. Gates, "Soil bulk density estimation methods: a review," Pedosphere, vol. 28, no. 4, pp. 581-596, 2018.

[22] S. Sertsu and T. Bekele, Procedures for Soil and Plant Analysis, National Soil Research Center, Addis Ababa, Ethiopia, 74, 2000.

[23] A. J. Walkley and I. A. Black, "Estimation of soil organic carbon by the chromic acid titration method," Soil Science, vol. 37, no. 1, pp. 29-38, 1934.

[24] J. Bremner, "Determination of nitrogen in soil by the kjeldahl method," The Journal of Agricultural Science, vol. 55, no. 1, pp. 11-33, 1960.

[25] A. Mehlich, "Mehlich 3 soil test extractant: a modification of mehlich 2 extractant," Communications in Soil Science and Plant Analysis, vol. 15, no. 12, pp. 1409-1416, 1984.

[26] H. D. Chapman, "Cation exchange capacity," in Methods of Soil Analysis, C. A. Black, Ed., pp. 891-901, American Society of Agronomy, Madison, WI, USA, 1965.

[27] S. R. Olsen and L. E. Sommers, Methods of Soil Analysis: Chemical and microbiological properties Part 2, American Society of Agronomy, Soil Science Society of America, Madison, Wisconsin, 1982.

[28] M. R. Carter and E. G. Gregorich, Soil Sampling and Methods of Analysispp. 265-291, CRC Press, Boca Raton, FL, USA, 2nd edition, 2007.

[29] K. A. B. Logan, M. J. S. Floate, and A. D. Ironside, "Determination of exchangeable acidity and exchangeable aluminum in hill soils part 1 exchangeable acidity," Communications in Soil Science and Plant Analysis, vol. 16, no. 3, pp. 301-308, 1985.

[30] E. O. Mclean, Aluminium in Methods of Soil Analysis, America Science Agronomy, Madison, WI, USA, 1965.

[31] H. E. Shoemaker, E. O. McLean, and P. F. Pratt, "Buffer methods for determining lime requirement of soils with appreciable amounts of extractable aluminium," Soil Science Society of America, vol. 25, no. 4, pp. 274-277, 1961.

[32] R. L. Westerman and W. Van Lierop, "Soil pH and lime requirement determination," SSSA Book Series, Wiley, vol. 3pp. 74-126, Hoboken, NJ,USA, 3rd edition, 1990.

[33] F. Mosissa, T. Balemi, and G. Keneni, "Effect of lime rates and incubation periods on the amelioration of acidic nitisols of Bedi area in Ethiopia," Journal of Agricultural Science and Soil Sciences, vol. 7, no. 7, pp. 087-093, 2019.

[34] G. W. Petersen and R. B. Corey, "A modified Chang and Jackson procedure for routine fractionation of inorganic soil phosphates," Soil Science Society of America Journal, vol. 30, no. 5, pp. 563-565, 1966.
[35] F. Fanjana, W. Haile, and G. Mitike, "Phosphorus fractionation and $\mathrm{P}$ sorption capacities of fincha sugar estate soils, western Ethiopia," African Journal of Agricultural Research, vol. 12, no. 25, pp. 2131-2139, 2017.

[36] J. F. Dormaar and G. R. Webster, "Determination of total organic phosphorus in soils by extraction methods," Canadian Journal of Soil Science, vol. 43, no. 1, pp. 35-43, 1962.

[37] E. Rydin, B. Huser, and E. B. Welch, "Amount of phosphorus inactivated by alum treatments in Washington lakes," Limnology and Oceanography, vol. 45, no. 1, pp. 226-230, 2000.

[38] A. M. Wailare and A. I. Madu, "Yield variability of Irish potato (Solanum tuberosum L.) as affected by cultivars and sowing date in the Sudan Savanna zone of Nigeria," Journal of Dryland Agriculture, vol. 5, no. 4, pp. 33-41, 2019.

[39] C. S. De Silva, I. S. A. Koralage, P. Weerasinghe, and N. R. N. Silva, "The determination of available phosphorus in soil: a quick and simple method," OUSL Journal, vol. 8, no. 1, pp. 1-17, 2015.

[40] C. J. Penn and J. J. Camberato, "A critical review on soil chemical processes that control how soil $\mathrm{pH}$ affects phosphorus availability to plants," Agriculture, vol. 9, no. 6, p. 120, 2019.

[41] A. Chimdi, E. Martti, and Y. Kari, "Sequential fractionation patterns of soil phosphorus collected from different land use systems of Dire Inchine district, west Shawa zone, Ethiopia," American-Eurasian Journal of Scientific Research, vol. 9, no. 3, pp. 51-57, 2014.

[42] K. Dinkecha and D. Tsegaye, "Effects of liming on physicochemical properties and nutrient availability of acidic soils in Welmera Woreda, central highlands of Ethiopia," Biochemistry and Molecular Biology, vol. 2, no. 6, pp. 102-109, 2017.

[43] J. S. Park and H. M. Ro, "Early-stage changes in chemical phosphorus speciation induced by liming deforested soils," Journal of Soil Science and Plant Nutrition, vol. 18, 2018.

[44] N. P. Mkhonza, N. N. Buthelezi-Dube, and P. Muchaonyerwa, "Effects of lime application on nitrogen and phosphorus availability in humic soils," Scientific Reports, vol. 10, no. 8634, pp. 1-12, 2020.

[45] K. N. Das and B. Seema, "Phosphorus forms and sorption characteristics in soils of a transect of Kohora watershed of Assam India," International Journal of Current Research, vol. 8, no. 11, pp. 41571-41579, 2016.

[46] M. Zhang, A. K. Alva, Y. C. Li, and D. V. Calvert, "Aluminum and iron fractions affecting phosphorus solubility and reactions in selected sandy soils," Soil Science, vol. 166, no. 12, pp. 940-948, 2001.

[47] M. J. Quiroga, M. Á. Olego, M. Sánchez-García et al., "Effects of liming on soil properties, leaf tissue cation composition and grape yield in a moderately acid vineyard soil. Influence on must and wine quality," OENO One, vol. 51, no. 4, pp. 343-362, 2017.

[48] A. Buni, "Effects of liming acidic soils on improving soil properties and yield of haricot bean," Journal of Environmental and Analytical Toxicology, vol. 5, no. 1, p. 248, 2014.

[49] A. J. Margenot, R. Sommer, and S. J. Parikh, "Soil phosphatase activities across a liming gradient under long-term managements in Kenya," Soil Science Society of America Journal, vol. 82, no. 4, pp. 850-861, 2018.

[50] National Research Council, Soil and Water Quality: An Agenda for Agriculture, The National Academies Press, Washington, DC, USA, 1993.

[51] W. H. Schlesinger and E. S. Bernhardt, Biogeochemistry: An Analysis of Global Change, Elsevier, Amsterdam, Netherlands, 3rd edition, 2013. 
[52] J. P. Chad and J. C. James, "A critical review on soil chemical processes that control how soil $\mathrm{pH}$ affects phosphorus availability to plants," Agriculture, MDPI, Open Access Journal, vol. 9, no. 6, pp. 1-18, 2019.

[53] L. B. Braos, M. C. P. d. Cruz, M. E. Ferreira, and F. Kuhnen, "Organic phosphorus fractions in soil fertilized with cattle manure," Revista Brasileira de Ciência Do Solo, vol. 39, no. 1, pp. 140-150, 2015.

[54] M. D. Ron Vaz, A. C. Edwards, C. A. Shand, and M. S. Cresser, "Phosphorus fractions in soil solution: influence of soil acidity and fertilizer additions," Plant and Soil, vol. 148, no. 2, pp. 175-183, 1993.

[55] T. Balemi and K. Negisho, "Management of soil phosphorus and plant adaptation mechanisms to phosphorus stress for sustainable crop production: a review," Journal of Soil Science and Plant Nutrition, vol. 12, no. 3, pp. 547-562, 2012.

[56] J. T. Sims, A. N. Sharpley, G. M. Pierzynski, and R. W. McDowell, "Chemistry, cycling, and potential movement of inorganic phosphorus in soils," Agronomy Monograph, no. 46, pp. 53-86, 2005.

[57] J. T. Sims, "Soil test phosphorus," in Methods of Phosphorus Analysis for Soils, Sediments, Residuals, and Waters, Southern Cooperative Series Bulletin No. 396, G. M Pierzynski, Ed., Kansas State University, Manhatten, NY, USA, 2000.

[58] L. M. Condron, H. Tiessen, C. Trasar-Cepeda, J. O. Moir, and J. W. B. Stewart, "Effects of liming on organic matter decomposition and phosphorus extractability in an acid humic ranker soil from northwest Spain," Biology and Fertility of Soils, vol. 15, no. 4, pp. 279-284, 1993.

[59] N. Athanase, R. Vicky, N. M. Jayne, and C. R. Athanase, "Effects of unburned lime on soil $\mathrm{pH}$ and base cations in acidic soil," ISRN Soil Science, vol. 2013, Article ID 707569, 7 pages, 2013.

[60] M. Barman, L. M. Shukla, S. P. Datta, and R. K. Rattan, "Effect of applied lime and boron on the availability of nutrients in an acid soil," Journal of Plant Nutrition, vol. 37, no. 3, pp. 357-373, 2014.

[61] N. S. Aye, P. W. G. Sale, and C. Tang, "The impact of longterm liming on soil organic carbon and aggregate stability in low-input acid soils," Biol Fertil Soils, vol. 52, no. 5, pp. 697-709, 2016.

[62] T. Chatzistathis, D. Alifragis, and A. Papaioannou, "The influence of liming on soil chemical properties and on the alleviation of manganese and copper toxicity in Juglans regia, Robinia pseudoacacia, Eucalyptus sp. and Populus sp. plantations," Journal of Environmental Management, vol. 150, pp. 149-156, 2015.

[63] T. M. Inagaki, J. C. de Moraes Sá, E. F. Caires, and D. R. P. Gonçalves, "Lime and gypsum application increases biological activity, carbon pools, and agronomic productivity in highly weathered soil," Agriculture, Ecosystems and Environment, vol. 231, pp. 156-165, 2016.

[64] G. G. Jezile, D. G. Westfall, G. Peterson, D. R. Child, D. P. Turner, and W. Van Averbeke, "Effects of liming on microbial activity and $\mathrm{N}$ mineralization in broiler manure amended soils from Bizana, eastern Cape, south Africa," South African Journal of Plant and Soil, vol. 26, no. 1, pp. 18-23, 2009.

[65] A. Moreira and N. Fageria, "Liming influence on soil chemical properties, nutritional status and yield of Alfalfa grown in acid soil," Revista Brasileira de Ciência do Solo, vol. 34, pp. 1231-1239, 2010.
[66] T. Ameyu, "A review on the potential effect of lime on soil properties and crop productivity improvements," Journal of Environment and Earth Science, vol. 9, no. 2, pp. 17-23, 2019.

[67] T. Han, A. Cai, K. Liu et al., "The link between potassium availability and soil exchangeable calcium, magnesium and aluminum are mediated by lime in acidic soil," Journal of Soils and Sediments, vol. 19, no. 1, pp. 1382-1392, 2019.

[68] B. Rutkowska, W. Szulc, and K. Bomze, "Effects of soil properties on copper speciation in soil solution," Journal of Elementology, vol. 18, no. 4, pp. 695-703, 2013.

[69] Y. Wen, J. Xiao, B. A. Goodman, and X. He, "Effects of organic amendments on the transformation of fe (oxyhydr)oxides and soil organic carbon storage," Frontiers in Earth Science, vol. 7, no. 257, pp. 1-15, 2019.

[70] B. Lalljee and S. Facknath, "Effect of lime on nutrient content of soils, yield and nutrient content of potato and infestation by leafminers," in Proceedings of the AMAS 2001, pp. 139-147, Food and Agricultural Research Council, Réduit, Mauritius, January 2001.

[71] N. V. Hue and Y. Mai, "Manganese toxicity in watermelon as affected by lime and compost amended to a hawaiian acid oxisol," HortScience, vol. 37, no. 4, pp. 656-661, 2002. 